\title{
レーザー解説
}

\author{
レーザー 誘雷 \\ 藤原閲 $*^{*}$ ・井澤靖 和*・河崎善一郎** \\ 松 浦 虔 $\pm^{* *}$. 山中 千代衛
}

（1991年 6 月19日＼cjkstart受理）

\section{Laser Triggered Lightning}

\author{
Etsuo FUJIW ARA * , Yasukazu IZAWA * Zen-ichiro KAWASAKI**, \\ Kenji MATSURA $^{* *}$ and Chiyoe YAMANAKA ***
}

(Received June 19, 1991)

\begin{abstract}
Electrical discharge guided by a $100 \mathrm{~J} / 2 \mathrm{GW}$ pulse $\mathrm{CO}_{2}$ laser is reviewed. A long air breakdown plasma channel is produced by using a Multi-Active $\mathrm{CHannel}(\mathrm{MACH})$ focusing mirror which has two focal lengthes. The plasma channel has been used to guide electrical discharge over a distance of $6 \mathrm{~m}$ in laboratory air at an applied potential of $-1.2 \mathrm{MV}$. A successive plasma channel produced by the laser is more effective for discharge guiding than the chains of break plasma beads. A stepped leader was obserbed with a streak camera for laser guided discharge. The mean propagation velocity of the stepped leader was $10^{5}-10^{6} \mathrm{~m} / \mathrm{s}$.
\end{abstract}

Key Words: Laser, Lightning, Plasma, Discharge, Trigger.

\section{1.はじめに}

まばゆいばかりの稲妻と強烈な衝撃音を伴う 雷は人々に恐れを抱かせるとともに興味をかき 立ててやまない。他方, 停電事故の約 $2 / 3$ は落 雷によるものであり，何とかならないかという 電力会社の担当者の声もある切実な問題であ る。雷研究とさらに一歩進めた誘雷はロマンと 実益を合わせ持ったテーマであるといえる。誘 雷のためにいろいろな方式が考案された。後述
のワイヤ付ロケット法, レーザー法の他にもフ ランクリンで有名な金属ワイヤで引っ張られた 凩や飛行船型バルーン法, あるいは荷電粒子 ビームやマイクロ波, 変わったところでは水鉄 砲 ${ }^{1)}$ というのもある。凩や水鉄砲は風に流され 易い欠点があるとされており，現在までにワイ ヤ付ロケット法だけが誘雷に成功している。

大出力のレーザー光を集光すると, 気体中に 絶縁破壊プラズマを生成することができる。こ のレーザー生成プラズマを避雷針として利用

*大阪大学レーザー核融合研究センター (7565 吹田市山田丘2-6)

$* *$ 大阪大学工学部電気工学科 ( 7565 吹田市山田丘2-6)

***(財)レーザー技術総合研究所 (干550大阪市西区靫本町1丁目8-4)

* ILE Osaka University (2-6 Yamadaoka, Suita, Osaka 565)

* * Department of Electrical Engineering, Faculty of Engineering, Osaka University (Yamadaoka, Suita, Osaka 565)

*** Institute for Laser Technology (1-8-4 Utsubo Honmachi, Nishiku, Osaka 550) 
し，そのプラズマに沿って雷放電を誘導するこ とが1970年代に提案された ${ }^{2)}$ 。その後，1979年 に米国New Mexicoにおいてレーザー誘雷の実 験が行われた3)。しかしこのときは $500 \mathrm{~m}$ 上空で 数 $\mathrm{m}$ のプラズマ発生には成功したものの実現に は至らなかった。他方，1965年から始まったワ イヤ付ロケット誘雷によって数多くの成功が報 告された。ロケット法はボビンに巻かれた直径 $0.2 \mathrm{~mm}$ 程度のスチールワイヤをプラスチック製 の小型ロケットに結び付けて上空に発射する方 式である。スチールワイヤは主放電 (帰還雷撃) の前のリーダの進展過程ですでにプラズマ化 し, 落雷はこのようなプラズマに沿って起こる。 ロケット誘雷はフランスのグループによって 200 回近い成功を収め，わが国でも昭和 52 年か らスタートして100回以上の誘雷に成功し, 多 くの輝かしい成果を収めている4)。しかしロ ケット誘雷ではロケットを使用すること, 金属 ワイヤを打ち上げることに伴う多くの制約があ ることも事実である。レーザー誘雷ではスチー ルワイヤに代わってレーザーで大気中にプラズ マ誘導路を形成する方式である。ロケット誘雷 ではその高度が $100 \mathrm{~m}$ 程度あれば誘雷が可能な ことを示しており ${ }^{4)}$, ロケット法と同程度の長 さのプラズマチャンネルを作る必要があると考 えられている。ロケット誘雷と比較するとレー ザー誘雷の利点として, 時間応答性が良いため に雷放電に対応しゃすく，また繰り返し動作に も向いているために実用化により適している点 が上げられる。レーザー技術の進歩に伴って， 誘雷をターゲットにした放電誘導実験も行われ るようになってきた ${ }^{5-12)}$ 。このようなレーザー 誘雷研究は, 停電の少ない高品質な電力供給を 目指す日本が最も熱心であり, 電力中央研究所, 慶応大学, 名古屋大学, 京都大学, (財) レーザー 技術総合研究所と大阪大学のグループ，九州大 学で活発な研究が進められている。また国外で は上昇中のロケットへの落雷経験のあるフロリ ダのNASAが雷予知を含めて熱心である。

レーザー誘雷の実現のためには, (1)レーザー による長尺プラズマチャンネルの発生技術, (2)
得られたレーザープラズマへの放電誘導特性, および(3)レーザーの大気中での吸収・散乱特 性の把握が重要である。さらにレーザーの照射 タイミングを決める落雷予知技術も不可欠であ り,これらが組合わさってレーザー誘雷が実現 可能になろう。レーザー誘雷研究は端緒につい たばかりであり，ここではレーザーによる長尺 プラズマチャンネルの発生を中心に述べる。

\section{2.レーザーの選択}

どのような波長のレーザーが誘雷に適してい るのであろうか? その前にレーザー誘雷には 2 種類の方法が考案されている。一方は高強度パ ルスレーザーを大気中で集光することによって 気中絶縁破壊によるプラズマを発生させ，得ら

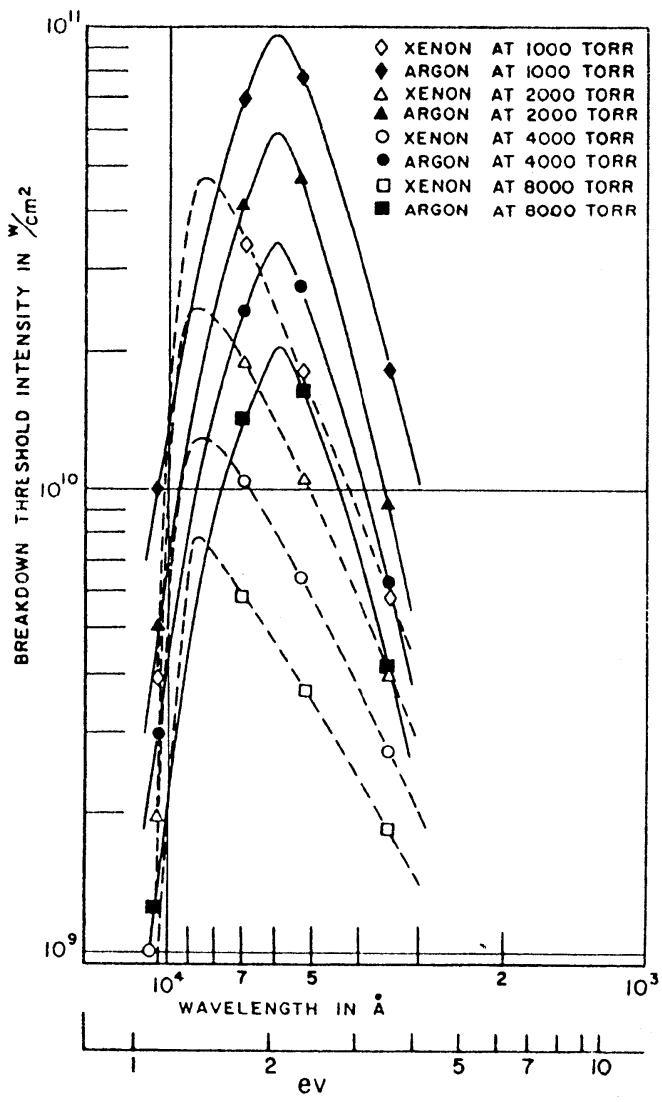

Fig.1 Breakdown threshold intensity versus wavelength of input laser at four selected pressures $^{13)}$. 


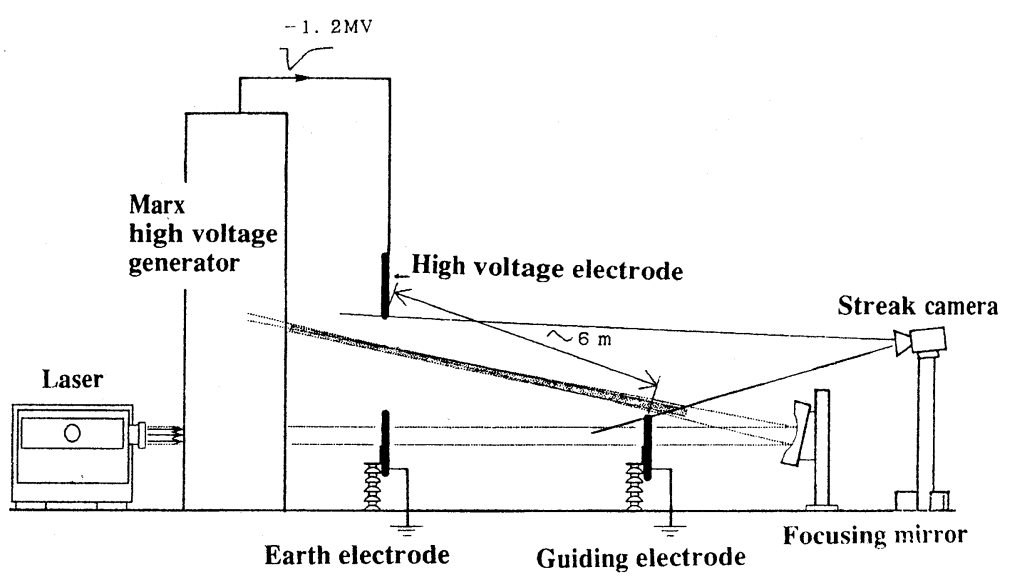

Fig. 2 Schematic diagram of the experimental facility. $\mathrm{A} \mathrm{CO}_{2}$ laser of $100 \mathrm{~J} / 2 \mathrm{GW}$ produces plasma channels between two electrodes.

れたプラズマに沿って放電を誘導するプラズマ チャンネル方式である。他方は高エネルギー レーザーを集光せずにそのまま大気中に照射 し，そのエネルギーによって大気を加熱・高温 度化する方式である。高温度となった空気は膨 張し，その中心は密度の低い放電路になりやす い領域を形成する。希薄化チャンネル方式と呼 ばれるが，プラズマチャンネル法よりも高出力 レーザーが必要であり, 大気中での基礎実験例 がほとんどないのが現状である。

プラズマチャンネル法に限ると，レーザーの 選択は，どのような波長のレーザーがプラズマ を作り易いかに言い換えることができる。 Fig.1はプラズマ発生に必要なレーザー強度の 波長依存性を示している ${ }^{13)}$ 。波長 $1 \mu \mathrm{m}$ 付近が 最も臨界レーザー強度が高い，すなわち最もプ ラズマをつくり難い波長であるといえる。それ よりも長波長側では高周波放電過程あるいは逆 制動輻射過程による電子加速によって臨界レー ザー強度が下がってくる。他方, 短波長側では 多光子吸収電離過程によって短波長レーザーほ ど臨界レーザー強度が下がってくる。レーザー の選択は, 両極端の波長, すなわち遠赤外線レー ザーあるいは紫外線レーザーの中で高出力レー ザーを捜すことから始まる。これまでのところ 最も高出力が得られているレーザーは，遠赤外
では $\mathrm{CO}_{2}$ レーザー(波長 $\left.10.6 \mu \mathrm{m}\right)$ であり，紫外 ではエキシマレーザーである。放電誘導研究の 初期にはガラスレーザー(波長 $1.06 \mu \mathrm{m})$ も使用

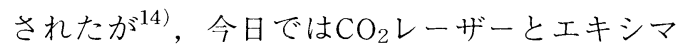
レーザーの両レーザーが主に使用されている。

\section{3. 実験装置}

パルス炭酸ガスレーザーと新たに開発した集 光鏡を用いて，レーザーによる長尺プラズマ チャンネルの生成と長ギャップ放電誘導の実験 を行なった。実験の配置をFig.2に示す。電極 には電圧印可側と接地側の両方に先端を半球に した直径 $3 \mathrm{~cm}$ の棒電極を使用している。レー ザーは $15 \mathrm{~m}$ 伝播した後，集光用の凹面鏡で反射 して誘導用接地電極と高電圧を印加する上部棒 電極間にプラズマチャンネルを発生させてい る。放電用の高電圧電源にはインパルス高電 圧発生装置 $(\mathrm{IG})$ を用いて扮り, 出力電圧は $1.2 \mathrm{MV}$ ，電圧の立ち上がり時間 $(10 \%-90 \%)$ は $2 \mu \mathrm{s}$ ，波尾は55 $\mu$ sである。実験では，誘導用 接地電極をかすめる様にしてレーザーを照射し た。

\section{1 レーザー装置}

レーザーには電子ビーム制御のパルス炭酸ガ スレーザー(波長 $10.6 \mu \mathrm{m})$ を用いた。レーザー 


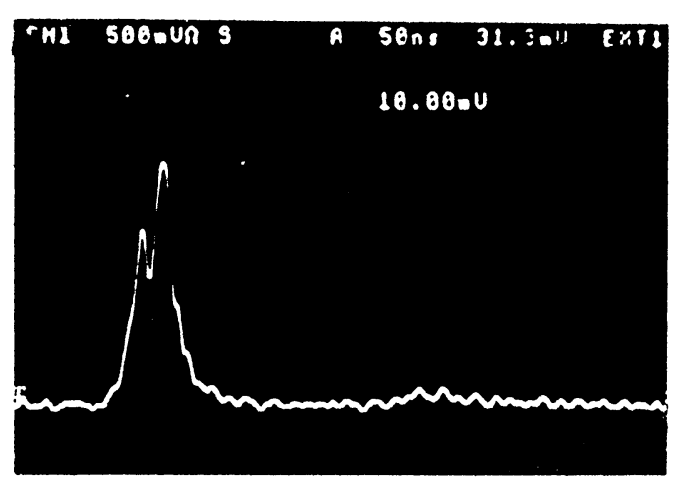

50ns/div.

Fig. 3 Pulse shape of a $100 \mathrm{~J} \mathrm{CO}_{2}$ laser. The cavity is a positive branch unstable resonator.

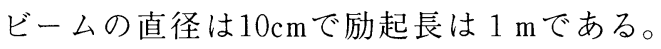
レーザーの集光強度を高くする必要から，レー ザービームの発散角の低減は特に重要であり,

そのために共振器には正ブランチの不安定共振 器を採用した。レーザー出力は100Jである。フォ トンドラッグ検出器によってレーザー光のパル ス波形を測定した結果をFig.3に示す。半值幅 $40 \mathrm{nsec}$ の最初の鋭いピークとその約 $200 \mathrm{nsec}$ 後 に2 度目の低いピークがあり弱い発振のテール が続いている。レーザーのピークパワーは 2 GWであった。

\section{2 集光光学系}

従来は球面の凹面反射鏡あるいは凸レンズが 用いられており，長いプラズマチャンネルを発 生するためには, $f / D$ の大きい $(f:$ 凹面鏡の焦 点距離, $D$ : レーザービームの直径) 凹面鏡を もちいて集光部分の長さを長くしていた。しか しその結果として以下のような問題が生じてい た。

（イ）集光部分の直径が大きくなり, 集光強度 が上がらないためにプラズマチャンネルの発生 が困難になる。

（ロ）つながったプラズマチャンネルではなく， ビーズ状の途切れたプラズマになりやすい。こ のような途切れたプラズマは放電誘導にはあま り適さない。

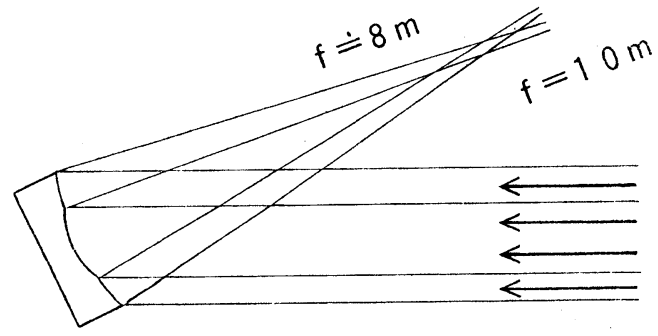

Fig.4 Multi Active CHannel (MACH) focusing mirror.

（ハ）大気中に生成したプラズマは $\mathrm{CO}_{2} レ ー$ ザーを吸収してしまい,レーザーはプラズマを 透過できない。そのために球面鏡では焦点位置 以遠に長いプラズマを作ることが困難である。

この様な問題に対して, 一枚の鏡の中に複数 の焦点を持つ多焦点 MACH (Multi-Active CHannel) 集光鏡を新たに考案し実験に導入し た (Fig.4)。MACH鏡では，中央部で反射した レーザーは鏡に近い位置に集光し，鏡の周辺部 で反射したレーザーは遠方に集光するように設 計している。その結果として，レーザーは前方 で発生したプラズマの影響を受けずにそれより も遠方に集光でき，より長いプラズマを発生す ることができる。また凹面鏡のように，集光部 分の一点に必要以上のエネルギーの集中が起こ るのではなく, $\mathrm{MACH}$ 鏡では集光エネルギーの 分散を図ることができるために少ないレーザー エネルギーで長いプラズマを作ることができ る。

実験では 2 種類の集光鏡を準備した。一方は $\mathrm{MACH}$ 鏡であり, 焦点距離 $10 \mathrm{~m}$ と $8 \mathrm{~m}$ の凹面鏡 を組み合わせた 2 焦点を持たせている。各焦点 への集光エネルギーは鏡の面積比から $1: 1$ と した。他方の鏡は，比較のために焦点距離 $10 \mathrm{~m}$ の通常の山面鏡 (以後 $R 20$ 鏡という) を準備し た。

\section{4.レーザーによるプラズマの発生}

プラズマチャンネルの測定はスチールカメラ による写真撮影によって求めた。レーザーの出 力は本実験を通して100J一定の条件で実施し 


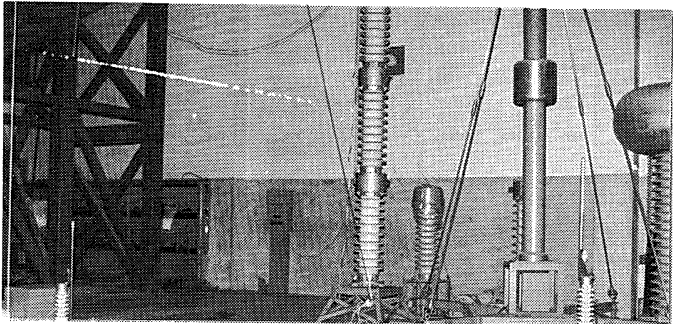

(a)

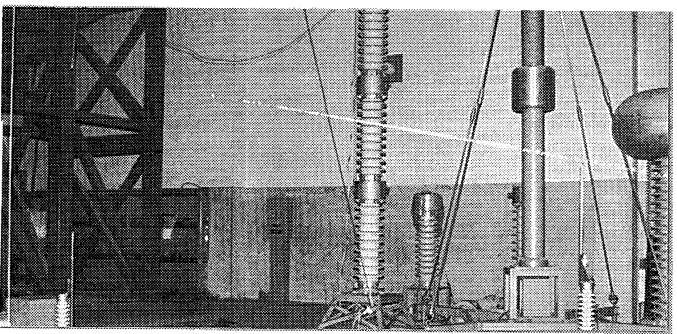

(b)

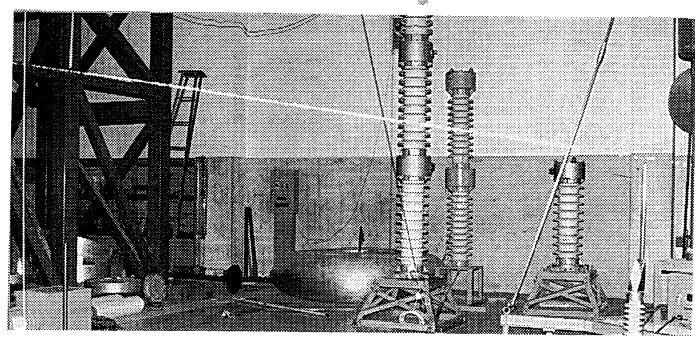

(c)

Fig.5 Time integrated photographs of laser plasmas produced by an outside mirror (a), an inside mirror (b), and two mirrors (c) of a $\mathrm{MACH}$ focusing mirror .

た。集光鏡には $\mathrm{MACH}$ 鏡を使用している。 Fig. 5 (a) はMACH鏡の内円部のミラーを覆って 外周部のミラーだけでプラズマを生成した写真 を，(b)は内円部のミラーだけでプラズマを生 成した写真を，(c)は覆いを取り省いて 2 焦点 で集光した写真を示す。(a)と（b）を足し合わ せた結果が $(\mathrm{c})$ であることを示しており， $\mathrm{MACH}$ 鏡ではそれぞれのミラーで作られるプラ ズマの重㸚合わせで長いプラズマを作ることが できる。このことはスケーリング則を立てる上 で非常に都合がよい。写真観測による連続的な プラズマチャンネルの長さは, 凹面鏡では約 3 m強，MACH鏡では約 5 mであった。またレー
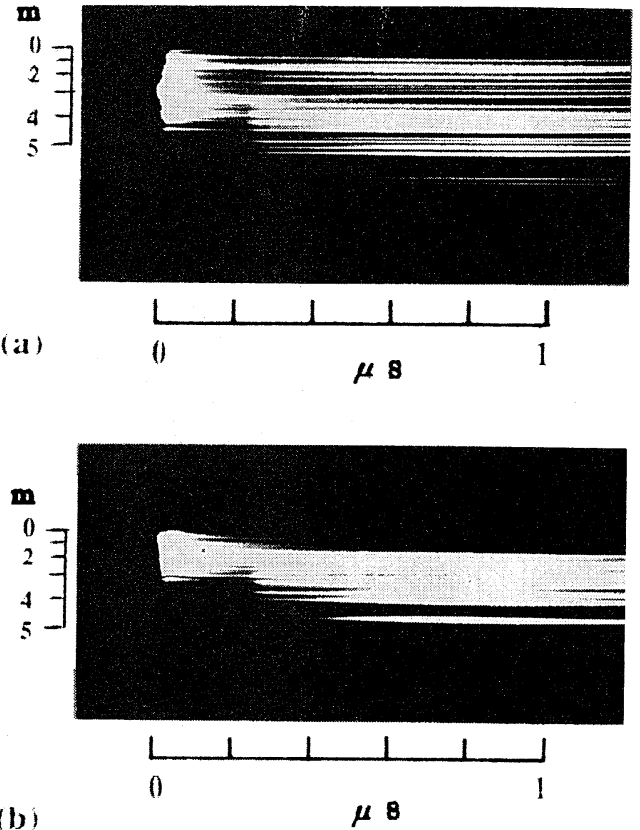

Fig. 6 Streak camera images of a laser produced plasma. (a) The MACH mirror (focal lengthes of $10 \mathrm{~m}$ and $8 \mathrm{~m}$ ), (b) A mirror with a $10 \mathrm{~m}$ focal length.

ザーの集光点以遠では，プラズマによってレー ザーが吸収されてしまうために長いプラズマ チャンネルは生成されず, 約 $0.5 \mathrm{~m}$ 程度の弱い 連続的なプラズマが観測されている。焦点の後 方 $2 \mathrm{~m}$ の位置に直径 $10 \mathrm{~cm}$ のエネルギーメー夕を 置き, レーザーの透過エネルギーからプラズマ による吸収率を求めた。吸収率は $R 20$ 鏡での $84 \%$ に対して，MACH鏡では $76 \%$ と若干少ない， 值は示すものの，3/4以上のエネルギーが吸収 されていることから実用上の問題はないと思わ れる。 MACH鏡では集光エネルギーの分散を 図っており，その結果単焦点鏡に見られる集光 点付近の密度の高いプラズマによるレーザー光 の強い吸収が少ないために透過光が若干多いと 考えられる。

可視のストリークカメラを用いてレーザープ ラズマの発光からプラズマが成長する過程を調 べた。MACH鏡とR20鏡について測定した結果 をFig.6に示す。図では高電圧電極の位置を $0 \mathrm{~m}$ 
にしている。 $R 20$ 鏡を用いた場合には，エネル ギー密度の高い鏡の焦点の位置から絶縁破壊が 始まって集光鏡側 (図では下方向)へ順次プラズ マが形成されていく。他方, MACH鏡の場合は, 光が先に到達する内円部の焦点位置 $(2.5 \mathrm{~m}$ 位 置) から両方向にプラズマ領域が進行しており, 外周部の焦点 $(0.5 \mathrm{~m}$ 位置)すぎまで発光が見ら れる。ストリーク写真から得られたプラズマの 成長速度は光速の $1 / 3 \sim 1 / 4$ と速い。また最初の 強い発光の後 $240 \mathrm{nsec} て ゙$ 再び発光が強くなり, 以後600nsecの間緩慢な増大が続き，その後ま た減衰していく。これはレーザーのパルス波形 に対応しており，高強度のレーザーパルスに続 く弱いテール部分のレーザー光もプラズマの加 熱には有効なことがわかる。

他方，新しい試みとしてこれまで述べてきた ような高強度レーザーを使用するかわりに，少 ないレーザーのエネルギーでプラズマを発生す る実験も行われている。TEA炭酸ガスレーザー と XeClエキシマレーザー(波長0.308 $\mu \mathrm{m}$ ) を重 睍した基礎実験では，まずエキシマレーザーで 予備電離プラズマを大気中に生成し, 続いて炭 酸ガスレーザーを照射して予備電離プラズマを 加熱し, 高密度プラズマを発生することに成功

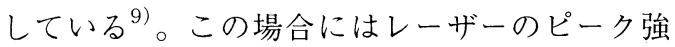
度を少なくできる特徵がある。

\section{5. 放電誘導}

上記の出力 $100 \mathrm{~J} \mathrm{CO}_{2}$ レーザーを使用し, IG からの出力電圧はー $1.2 \mathrm{MV}$ 印加の条件で測定 した。この電圧での $50 \%$ の確摔でフラッシオー バが起こる電極間距離は $1.6 \mathrm{~m} \sim 1.7 \mathrm{~m}$ の間で あった。遅延時間は, 最も放電誘導が起こり易 いレーザー照射から $100 \mu \mathrm{s} の$ 後に電圧を印加す るようにした。 $R 20$ 鏡で集光した場合には，放 電誘導が可能な長さは $4 \mathrm{~m}$ までであった。それ に対してMACH鏡では同等のレーザー出力で 6 $\mathrm{m}$ までの放電誘導が可能であった。これまでの 報告が 2 〜 $\mathrm{m}^{6,12,15)}$ に留まっていたことか ら，放電誘導長の大幅な更新が達成されたとい える。MACH鏡を用いた場合の時間積分写真の

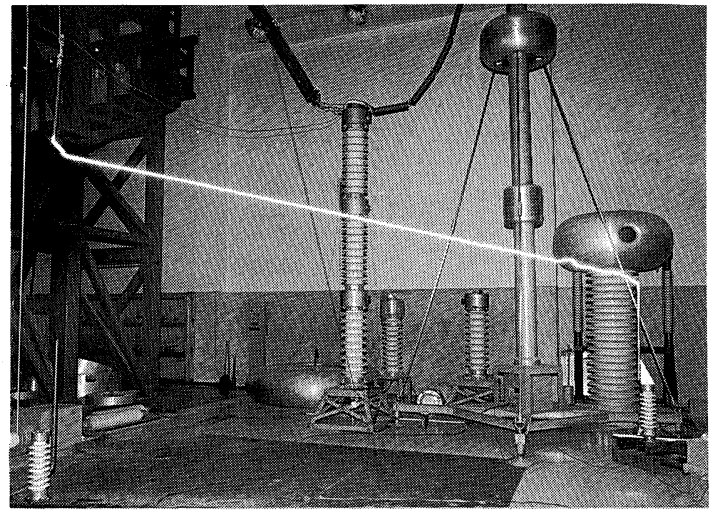

Fig.7 Time integrated photographs of laser guided arc. The electrode separation is $6 \mathrm{~m}$.

一例をFig.7に示す。レーザープラズマによっ てガイドされている部分は摇らぎのない一直線 に放電する特徵があるのに対して，十分にガイ ドされていない誘導用接地電極付近約 $1 \mathrm{~m}$ の領 域では，放電路のゆらぎあるいは光軸からのず れが観測された。ガイドされていない領域では, レーザープラズマはおよそ $10 \mathrm{~cm}$ 間隔以上の ビーズ状の離散的な分布を示しており，このよ うな離散的なプラズマ形状は放電誘導の効果が あまりないことがわかる。従って，途切れのな い連続したプラズマチャンネルを作ることが重 要であると言える。

ところでレーザー生成プラズマが導電性を持 つと言っても金属線のような訳にはいかないと 思ってよいであろう。弱電離プラズマ中をリー ダが成長するためには，電界強度はいかほど必 要であろうか? そのための予備実験として誘導 距離と放電誘導に必要な電圧の関係を調べた。 レーザー光路は上部電極と誘導用接地電極两方 の先端をかすめるように調整した。IGの出力 電圧波高值を $100 \mathrm{kV}$ 間隔で変え, 放電が誘導さ れた最低の電圧をFig.8に示す。この図より， 誘導距離 $5.5 \mathrm{~m}$ と $6.0 \mathrm{~m}$ の間で必要な電圧が急 激に増加している。このことはレーザーにより 生成されたプラズマがまばらになり, 誘導効果 を失う領域がこの間に存在することに対応して いる。他方， $5.5 \mathrm{~m}$ 以下では通常の気中放電と 


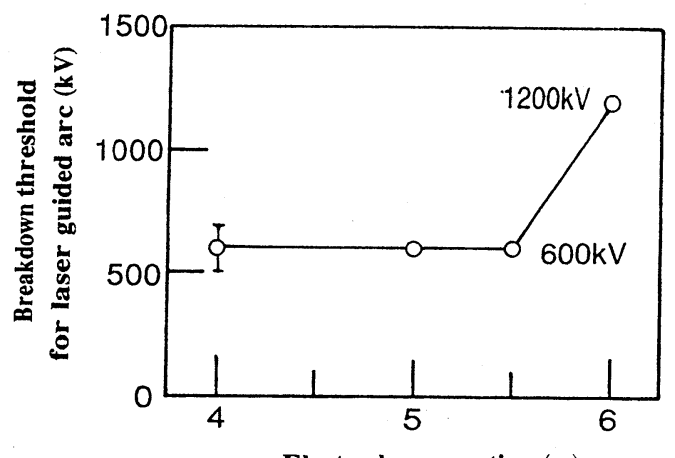

Electrode separation (m)

Fig. 8 Breakdown threshold voltages versus electrode separation for guided arcs. The focusing point of MACH mirror is under a high voltage electrode. The delay time is $100 \mu$ s.

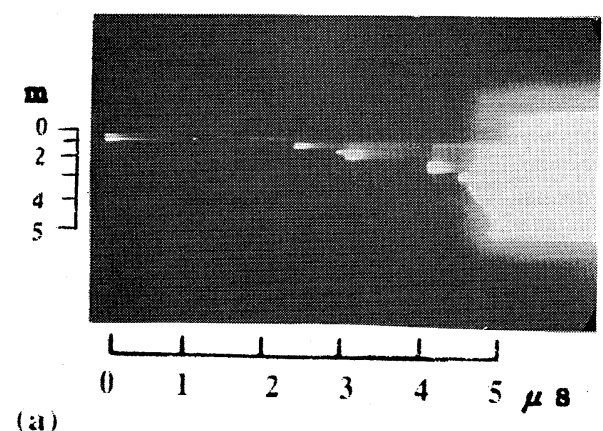

(a)

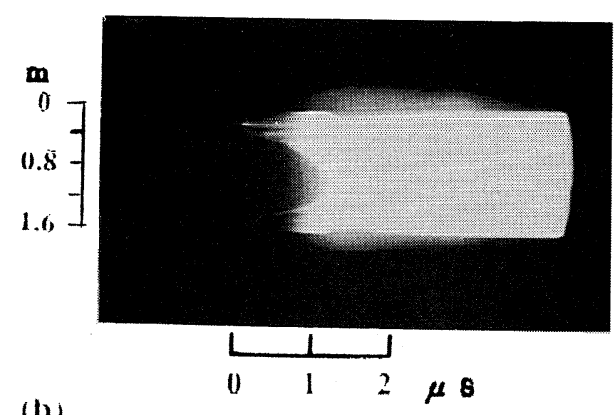

Fig.9 Streak camera images of arc discharges at an applied voltage of $-1.2 \mathrm{MV}$; (a) A laser guided arc. The electrode distance is $4.88 \mathrm{~m}$; (b) An unguided arc. The electrode distance is $1.6 \mathrm{~m}$.

異なって，放電に必要な電圧が電極間距離によ らず一定であった。棒電極ではその先端で強い
不均一電界を生じており，その影響と思われる が明かではない。均一電界中での測定が必要で ある。

さてレーザープラズマで誘導された放電と通 常の放電とでは放電路形成の様子は同じであろ うか?ストリークカメラによって，主放電に到 る前のリーダが進展する過程を観測した。典型 的な $5 \mathrm{~m}$ の放電誘導過程のストリーク像を Fig. 9 に示す。比較のために $1.6 \mathrm{~m}$ の通常の気中 放電のストリーク像も示す。

レーザー誘導の場合は，レーザー照射から $100 \mu \mathrm{s}$ の遅延時間をおいたので，レーザー光に よる光学的絶縁破壊の発光はすでに終了してい て写っていない。レーザー誘導ではリーダが高 電圧を印可した電極 (負電圧) からステップ状の 強い発光を伴って進展しており，通常のギャッ プ放電におけるなだらかな両電極からの連続し た進展とは明かに異なっている。ステップリー ダの進展速度は，ステップ状の強い発光の先端 を結んだ平均速度で与えると $10^{5}-10^{6} \mathrm{~m} / \mathrm{s}$ あ゙あ た。このようなステップリーダは自然雷で観測 されている特異な現象であり，その原因は必ず しも明かではない。大気中の短ギャップ放電で はこのような現象が現れていないことから，長 ギャップ放電あるいはレーザー誘導放電特有の 現象と思われ，この分野の解明にも寄与するも のと思われる。

遅延時間

レーザープラズマの寿命はどの程度であろう か?このことは複数のレーザーあるいは高繰り 返しのレーザーを使って一本の誘導路を形成す るときに重要である。実験では，レーザー照射 から $1 \mu \mathrm{s} \sim 1 \mathrm{~ms}$ の後に電圧を印加して放電誘 導の有無を調べた。上部電極と誘導用接地電極 との間隔は，連続したプラズマチャンネルの長 さに匹敵する $5 \mathrm{~m} に$ 選んでいる。各遅延時間で 5 回測定し, 遅延時間に対する放電誘導確率を 求めた結果をFig.10に示す。測定結果からは, 遅延時間 $200 \mu \mathrm{s}$ 以降では誘導効果が弱くなり 1 $\mathrm{ms}$ では誘導できないことを示しており，この あたりが誘導可能な時間限界といえる。また山 


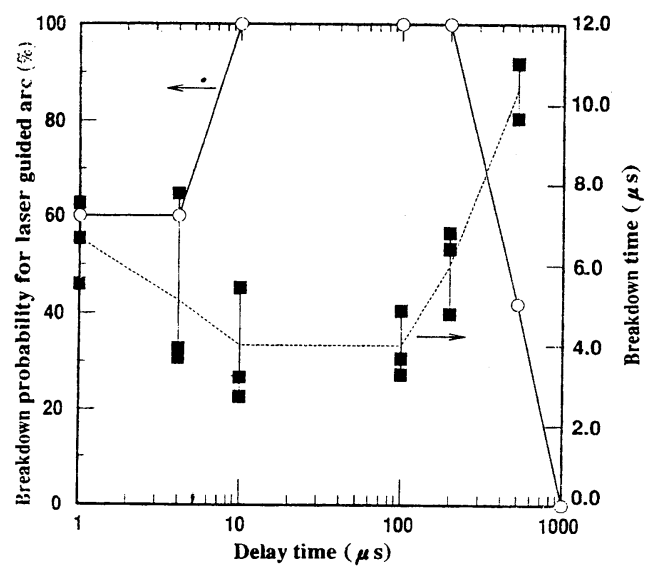

Fig.10 Breakdown probability of laser guided arc versus the delay time between the laser and impulse voltage.

部等は最大 $2.5 \mathrm{kHz}$ の高繰り返し $\mathrm{XeCl}$ エシシマ レーザーを用いて，繰り返し周波数とレーザー トリガーによる放電確率の測定をおこなっ た ${ }^{16)}$ 。2kHz以上の繰り返しでトリガー確率が 高くなることを示しており，プラズマの寿命に 関してほぼ同様の結果を得ている。またFig.10 での絶緑破壊時間は，立上り $2 \mu \mathrm{s}$ の IGからの出 力電圧が $80 \%$ に達した時間から放電開始までの 時間として定義している。

他方, 遅延時間が短い $4 \mu \mathrm{s}$ 以下でも放電誘 導確率の減少が見られた。一見奇妙であるが,

これは連続的に見えるプラズマチャンネルにお いても，拡大写真を取ると微少なプラズマの密 な集合体で構成されており, それぞれのプラズ マが拡散して連続してつながるまでの時間が関 係していると考えられる。微小プラズマは大気 中のほこりなどの吸収体がレーザーで加熱され プラズマ化したものと思われる。測定結果から は放電誘導に最も適した遅延時間は $10 \mu \mathrm{S} \sim 100$ 视であった。

ところでどのような荷電粒子が放電誘導に寄 与しているのであろうか。知られている反応定 数 ${ }^{17)}$ を用いてシミュレーションしたところ, レーザーで生成された電子の寿命はずいぶん短 く, 100ns以下の寿命でほとんどプラスイオン と再結合してしまう。しかし再結合しなかった
残りの電子は酸素に電子付着して酸素イオンと して残る。

$$
\begin{aligned}
\mathrm{e}+\mathrm{O}_{2} & \rightarrow \mathrm{O}_{2}^{-} \\
\mathrm{O}_{2}^{-}+\mathrm{h} \nu & \rightarrow \mathrm{e}+\mathrm{O}_{2}
\end{aligned}
$$

この酸素イオンの寿命はmsオーダーと長く, これが放電誘導の源と考えられている。電界あ るいは光によって酸素イオンから電子が容易に 飛び出し，それを種として電子なだれが進行す る。

\section{6 . 雷予知}

雷放電に伴って広い帯域にわたって電磁波が 放射される。1 $\mathrm{Hz} \sim 1 \mathrm{MHz}$ 程度までの広帯域で 帰還雷撃に伴う電磁波を受信し，その放射源の 位置測定を㧍こなう二つのシステムが実用化さ れている。一方は直交ループアンテナで磁界信 号を受信し，多点で方位測定を同時に行って位 置標定をするものでLLP (Lightning Location and Protection) システムと呼ばれている ${ }^{18-20) 。 ~}$ 他方は 4 点以上で電磁波の到着時間差を測定し て位置標定を行うものでLPATS (Lightning Positioning and Tracking System) システムと呼 ばれている21)。これらのシステムはすでに全 国に設置されており，落雷地点やその極性など を知ることができる。

しかしレーザー誘雷では, さらに高い精度で リアルタイムの雷雲位置標定システムが必要で あろう。フランスで開発されたVHF帯あるい はUHF带での干渉法によるリアルタイム電磁 波到来方位測定システムSAFIR (Systeme d'Alerte Foudre par Interferometric Radio electrique) は高い空間，時間分解能を持つとさ れており ${ }^{22)}$ ，日本でも研究が進められている。 また二重偏波レーダによる雷雲内の観測も始 まっている ${ }^{23)}$ 。レーザー誘雷には地上への落 雷以前の雲内放電やリーダ進展のキャッチが重 要であろう。

\section{7. 将来への展望}

レーザー誘雷の研究はスタートしたばかりで 


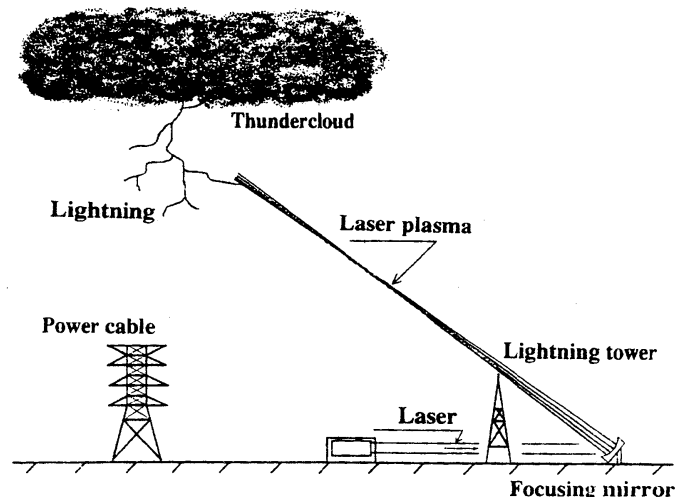

Fig.11 Schematic diagram of future laser tiggering lightning.

ある。その実現のためには、レーザーによる $100 \mathrm{~m}$ 級の長プラズマチャンネルの発生, 得ら れたレーザープラズマへの放電誘導，抄よびプ ラズマ発生部までのレーザーの大気中での透過 特性の把握, さらに雷予知も含めて幾つもの ハードルが待ち受けている。 $\mathrm{MACH}$ 鏡は長プラ ズマチャンネル発生への可能性を示したといえ る。もちろん大出力レーザーの技術開発は最重 要課題である。幸いなことに大阪大学レーザー 研で，レーザー核融合研究のために出力 $10 \mathrm{~kJ} の$ 炭酸ガスレーザー(烈光VIII号)がすでに開発さ れ, 稼㗢しているのは心強いかぎりである。レー ザー誘雷には烈光䜣号よりも少ないレーザー出 力で可能と思われるからである。今後の着実な 進展が望める分野であると言える。

将来のレーザー誘雷のイメージをFig.11に示 す。空から降りて来るリーダをレーザーで迎え 撃つ図ではあるが，実際にはレーザープラズマ の先端から逆にリーダが雷雲に向かって伸びて いくケースが多いと思われる。その場合には レーザーの照射タイミングが $\mu$ をを競うことは ないであろう。また $\mathrm{MACH}$ 鏡の段数は数 $10 \mathbf{E}^{\text {なに }}$ も及ぶため，連続的な曲面を持った鏡になるで あろう。光軸上の集光強度が一定になるような 鏡の曲面は次式で与えられる。レーザーは平行 ビームで，鏡に対して垂直に入射すると仮定し ている。

$$
\begin{aligned}
Y(r) & =1 /(2 a) *\left(\ln \left(r^{2}+h / g\right)-\ln \left(r_{1}^{2}+h / g\right)\right) \\
g & =(b-a) /\left(r_{2}^{2}-r_{1}^{2}\right) \\
h & =\left(a r_{2}^{2}-b r_{1}^{2}\right) /\left(r_{2}^{2}-r_{1}^{2}\right)
\end{aligned}
$$

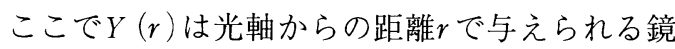
の反射曲面の座標， $r_{1}$ および $r_{2}$ はそれぞれ反射 鏡の内径と外径， $a, b$ はそれぞれ鏡の $r_{1}, r_{2}$ 位 置での反射光の焦点位置を与えている $(b>a)$ 。 このミラーは中心に穴が開いており，形状は例 えば朝顔の花のような外側に開いた曲面を持 つ。

\section{謝辞}

本研究に当たっては，大阪大学レーザー核融 合研究センターにおいてレーザー核融合実験に 使用されていた烈光 II 号炭酸ガスレーザーを使 用した。中井所長の厚意に感謝いたします。ま た本研究は関西電力株によってサポートされた ものであり, 関電総合技術研究所の永井敏雄, 園井康夫両研究員には多くのアドバイスを戴き 深く感謝いたします。

\section{参 考 文 献}

1）秋山秀典, 前田定男, 高木浩一：「水誘雷の 検討」電気学会高電圧研究会, HV-91-10 (1991) 87.

2) L. M. Ball: Appl. Opt., 13 (1974) 2292.

3）新藤，鈴木：「レーザーによる気体の絶縁破 壊と誘導」電力中央研究所報告 No.182010 (1982).

4) 堀井憲爾：電気学会誌，110巻1号 (1990) 21 .

5）内山, 広橋, 宮田, 坂井：レーザー研究, 16 巻5号 (1988) 267.

6）新藤，鈴木，相原，三木：電気学会放電高電 圧合同研究会, ED-90-166 (1990) 37.

7) 広橋, 栄, 坂井, 内山: 電気学会放電研究会, No.123 (1989) 45 .

8）首藤, 西村, 藤原, 河崎, 井澤, 松浦, 園井, 永井, 山中: 電気学会光・量子デバイス研究 会, OQD-91-7 (1991).

9）久保, 竹谷, 神野, 森岡, 板谷, 園井, 永井 : 電気学会高電圧研究会, HV-91-2 (1991) 9.

10) 鈴木, 中村, 山部, 堀井 : 電気学会高電圧研 究会, HV-91-3 (1991) 19.

11) 本田, 江藤, 村岡, 宅間, 吉岡, 片平, 池上, 
赤碕：電気学会高電圧研究会, HV-91-5 (1991) 39.

12) 広橋, 栄, 坂井, 内山: 電気学会放電研究会 「レーザー誘雷」No. 123 (1989) 45.

13) H. T. Buscher et al.: Phys. Rev. Lett., 15 (1965) 847.

14) D. W. Koopman et al.: J. Appl. Phys., 42 (1971) 1883.

15) J. R. Greig, D. W. Koopman, R. F. Fernsler, R. E. Pechacek, I. M. vitkovitsky, A. W. Ali: Phys. Rev. Lett., 41 (1978) 174.

16) 中村, 鈴木, 安田, 山部, 堀井, 後藤, 佐藤, 高木：電気学会高電圧研究会, HV-91-4 (1991) 29.
17) D. W. Koopman, K. A. Saum: J. Appl . phys., 44 (1973) 5328.

18）北條他：電気学会論文 B108 (1988) 165 .

19) R. E. Orville, et al.: Geophys. Res. Lett. 15 (1988) 129.

20) J. Hojo, et al.: J. Geophys. Res. 94 (1989) 13207 .

21) M. J. G. Janssen: Proc. 1989 Int. Conf. on Lightning and Static Electricity, Bath, 12A (1989) 2 .

22) P. Richard, et al.: Proc. 8th Int. Conf. Atomos. Electricity, Uppsala (1988) 687.

23) S. Fukao, Y. Maekawa, Y. Sonoi, F. Yoshino: Geophysical Research Letters, 18 (1991) 179. 